DOI: https://doi.org/10.47405/mjssh.v6i4.745

\begin{tabular}{|c|c|}
\hline $\log ^{2}$ & Malaysian Journal of Social Sciences and Humanities (MJSSH) \\
\hline Malaysian Journal of & Volume 6, Issue 4, April 2021 \\
\hline $\begin{array}{l}\text { Humantites } \\
\text { (MJ-sSH) }\end{array}$ & e-ISSN : 2504-8562 \\
\hline & $\begin{array}{l}\text { Journal home page: } \\
\text { www.msocialsciences.com }\end{array}$ \\
\hline
\end{tabular}

\title{
Persepsi Pengguna Internet di Malaysia Semasa Pandemik COVID-19
}

\author{
Nur Ain Md Lukmanul Hakim¹, Nur Aisyah Junaidun¹, Nurul Syazwani Mohamamd Fadzil1, \\ Mohamad Izzuan Mohd Ishar ${ }^{1}$ \\ 1Sekolah Pendidikan, Fakulti Sains Sosial dan Kemanusiaan, Universiti Teknologi Malaysia (UTM)
}

Correspondence: Nur Ain Md Lukmanul Hakim (nurainlukman6244@gmail.com)

\begin{abstract}
Abstrak
Internet dilihat sebagai alat komunikasi yang telah mempercepatkan, memudahkan perhubungan dan capaian maklumat secara meluas. Semenjak wabak COVID-19 menyerang pada awal tahun 2020 masyarakat hidup dalam perubahan yang berterusan. Perkembangan tahun- tahun terakhir dalam bidang komunikasi, teknologi, maklumat dan pemasaran telah menciptakan perubahan baru dalam cara pengguna internet dalam membeli produk dan perkhidmatan tertentu. Kajian yang dijalankan ini merupakan satu kajian deskriptif dimana kajian ini menggunakan reka bentuk kajian kuantitatif dan borang soal selidik sebagai instrumen kajian. Sasaran responden bagi kajian ini adalah pengguna internet di seluruh Malaysia. Selain itu, kajian ini turut memperlihatkan persepsi pengguna internet di Malaysia semasa pandemik COVID-19. Kajian yang dijalankan melalui edaran borang soal selidik secara atas talian kepada pengguna di Malaysia sebagai sasaran kajian. Keputusan daripada kajian tersebut telah menunjukkan persepsi pengguna internet di Malaysia semasa pandemik COVID- 19 menunjukkan bahawa internet merupakan satu keperluan utama dalam menjalankan tugas harian. Berdasarkan soal selidik, $91.3 \%$ responden yang menyatakan bahawa mereka sangat setuju bahawa internet merupakan keperluan utama. Walau bagaimanapun, dalam perubahan ini, pelbagai masalah, isu dan kesan akan timbul dalam kalangan individual atau masyarakat di negara ini.
\end{abstract}

Kata kunci: COVID-19, pengguna, internet

\section{Perceptions of Internet Consumer in Malaysia during COVID-19 Pandemic}

\begin{abstract}
The Internet is seen as a communication tool that has accelerated, facilitated communication and access to information widely. Since the outbreak of the COVID-19 in early 2020 the society that we live in is in a continuous state of change. The development of recent years in the fields of communication, technology, information, and marketing has created new changes in the way internet users in purchasing certain products and services. This study is a descriptive study where this study uses a quantitative study design and questionnaire form as a research instrument. The target respondents for this study are internet users throughout Malaysia. Besides, this study also shows the perception of internet users in Malaysia during the COVID-19 pandemic. The study was conducted through the distribution of online questionnaires form to consumers in Malaysia as the target of the study. The results of the study have shown that the perception of internet users in Malaysia during the COVID-19 pandemic shows that the internet is a key requirement in carrying out daily tasks. Based on the questionnaire, $91.3 \%$ of respondents stated that they strongly agree that the internet is the main
\end{abstract}


need. However, various problems, issues, and effects will arise among individuals or communities in the country.

Keywords: COVID-19, consumer, internet

\section{Pengenalan}

Internet merupakan wadah komunikasi yang telah mempercepatkan, memudahkan perhubungan dan capaian maklumat secara meluas. Menurut kajian, lebih 400 juta manusia dianggarkan menggunakan internet setiap hari bagi mencari maklumat dan sosial media. Internet merupakan rangkaian komputer terbesar di dunia dengan sumber maklumat global dimana maklumat boleh dicapai dalam beberapa saat sahaja. Internet membolehkan komunikasi dan pertukaran maklumat dilakukan secara bebas. Kita sedia maklum bahawa pengguna internet kini telah meningkat dari tahun ke tahun ibarat cendawan tumbuh selepas hujan. Mengikut statistik tinjauan pengguna internet 2020 daripada Malaysian Communications and Multimedia Commission (MCMC), jumlah pengguna internet meningkat 1.3\% berbanding pada tahun sebelumnya.

Daripada tinjauan itu juga mendapati antara aktiviti utama atas talian ialah komunikasi teks, media sosial, menonton video, panggilan atau komunikasi video dan carian informasi. Pada awal tahun 2020, dunia telah digemparkan dengan fenomena pandemik koronavirus atau dengan panggilan COVID-19 yang telah menyerang negara China pada awalnya dan kini telah merebak ke serata dunia termasuk Malaysia. Hal ini telah menyebabkan banyak sektor terjejas termasuk sektor pendidikan. Pendidikan di Malaysia terpaksa dijalankan atas talian sama ada di peringkat sekolah atau pengajian tinggi. Ramai rakyat Malaysia kehilangan pekerjaan dan kewangan terjejas. Setiap hari berlaku peningkatan kes di setiap negeri menyebabkan sektor pelancongan juga terjejas sekali gus kepada ekonomi negara. Oleh yang demikian, kajian ini dijalankan bagi melihat persepsi pengguna internet di Malaysia semasa pandemik COVID-19

\section{Objektif}

i. Mengenal pasti persepsi pengguna internet di Malaysia dari aspek hiburan semasa pandemik COVID-19.

ii. Mengenal pasti persepsi pengguna internet di Malaysia dari aspek perniagaan semasa pandemik COVID-19.

iii. Mengenal pasti persepsi pengguna internet di Malaysia dari aspek pekerja dan pelajar semasa pandemik COVID-19.

\section{Kajian Literatur}

\section{Pengguna Internet di Malaysia Semasa Pandemik COVID-19}

Menurut FMT Reporters (2020) yang melaporkan bahawa jabatan perangkaan mengatakan penembusan penggunaan internet isi rumah telah meningkat dari tahun 2018 kepada tahun 2019 dengan peratusan $87 \%$ kepada $90.1 \%$. peratusan penggunaan internet pada tahun 2020 juga dijangkakan akan meningkat dari tahun sebelumnya kerana berjuta-juta rakyat Malaysia banyak menghabiskan masa mereka dengan menatap peranti elektronik semasa tempoh perintah kawalan pergerakan yang di arahkan oleh kerajaan Malaysia bagi menahan dan membendung wabak COVID19 ini. Sebahagian besar pengguna internet di Malaysia aktif dalam rangkaian sosial dengan memuat turun gambar, filem, video, permainan, perisian, aplikasi, mencari maklumat dan membuat serta melanggan perkhidmatan. Ianya juga disokong oleh BERNAMA (2020) kerana dalam tempoh 
perintah kawalan pergerakan sepanjang COVID-19 ini internet telah menyumbang kepada peningkatan permintaan jalur lebar yang lebih tinggi sehingga menyebabkan kesesakan dan penurunan kelajuan muat turun. Mereka yang bekerja dalam memberikan perkhidmatan internet dan komunikasi kepada pengguna di Malaysia telah bertungkus lumus bagi memastikan kapasiti jalur lebar ditambah agar ia dapat menampung jumlah penggunaan pengguna.

Menurut Simon (2020) pada Januari 2020 rakyat Malaysia menghabiskan 7 jam 57 min dengan menggunakan internet. Sebanyak 26.69 juta pengguna internet di mana-mana peranti elektrik yang membawa peratusan sebanyak $83 \%$ dari populasi rakyat Malaysia. Seramai 25.86 juta pengguna internet dengan menggunakan telefon bimbit dengan peratusan $97 \%$ dari jumlah pengguna internet yang menghabiskan masa mereka dalam lingkungan 4 jam 3 minit. Purata kelajuan sambungan internet dan internet tetap di Malaysia masing-masing ialah $23.80 \mathrm{mbps}$ dan $78.03 \mathrm{mbps}$. Secara globalnya pada bulan November 2020 Malaysia berada pada peringkat ke 88 dengan $24.26 \mathrm{mbps}$ dari 139 buah negara dengan jalur lebar mudah alih. Manakala bagi jalur lebar tetap, Malaysia berada pada peringkat ke-43 dari 176 buah negara dengan 91.40mbps (Speedtest Global Index, 2020).

\section{Pandemik COVID-19 di Malaysia}

Coronavirus atau nama singkatannya ialah COVID-19 merupakan penyakit berjangkit yang baru ditemui di dunia seterusnya telah masuk ke Malaysia disebabkan oleh virus. Mereka yang dijangkiti virus COVID-19 ini akan mengalami masalah pernafasan yang teruk terutama sekali kepada warga tua (Rashid \& Hassan, 2020). Menurut Talha (2020) kes pertama COVID-19 di Malaysia telah disahkan pada 25 Januari 2020 dimana pada mulanya ia melibatkan tiga warga cina yang masuk ke Malaysia pada 23 Januari 2020 melalui negeri Johor dari negara Singapura. Dengan itu, kerajaan negara Malaysia terus menasihatkan rakyatnya untuk tidak melancong ke negara China kerana ia dikatakan virus ini pucuk utamanya adalah dari negara China. Perintah kawalan pergerakan (PKP) bermula pada 18 hingga 31 Mac 2020 di semua negeri di Malaysia. Namun disebabkan masih tiada penurunan yang ditunjukkan oleh bilangan kes positif COVID-19 di Malaysia kerajaan telah melanjutkan PKP fasa 2 sehingga suatu tempoh tertentu.

PKP yang dijalankan seterusnya akan memberikan impak kepada semua penduduk di Malaysia tidak kira yang tinggal di bandar atau di luar bandar. PKP mahupun Perintah kawalan pergerakan bersyarat (PKPB) merupakan satu tindakan yang dijalankan untuk mencegah penularan COVID-19. Impak daripada pandemik COVID-19 ini bukan sahaja akan tertumpu kepada ekonomi negara. Ia juga memberi kesan kepada aspek sosial penduduk. Penduduk di Malaysia mahupun di seluruh negara terpaksa merubah gaya hidup mereka berbanding sebelumnya. Berdasarkan bilangan kumulatif kes positif pada tarikh 8 April 2020 negara Malaysia berada pada tangga ke-31 daripada 183 negara yang terlibat dalam pandemik COVID-19 ini (Simon, 2020).

\section{Pengguna Internet di Malaysia dari Aspek Hiburan Semasa Pandemik COVID-19.}

Sebanyak 98\% rakyat Malaysia yang menghabiskan masa mereka dengan menonton video secara atas talian di YouTube dan 55\% menonton vlog. Manakala, 70\% rakyat Malaysia yang menggunakan perkhidmatan penstriman lagu, $56 \%$ yang menggunakan perkhidmatan konti radio dan $35 \%$ rakyat Malaysia yang mendengarkan podcast. Selain itu, pada awal tahun 2020 juga, penggunaan permain video di setiap jenis peranti seperti telefon pintar, komputer, konsol permainan dan komputer tablet adalah sebanyak $87 \%$. Di dalam peratusan ini, terdapat 6.7 peratus pengguna internet yang melanggan permainan video, $9.5 \%$ yang memainkan permainan video secara atas talian, $13 \%$ berkongsi video dan juga permainan. $27 \%$ pengguna yang menonton pemain lain bermain permainan video secara atas talian dan 13\% yang menonton kejohanan e-sport (Simon, 2020). Menurut Simon (2020) juga penggunaan sosial media meningkat dari April 2019 kepada Januari 2020 dengan 4.1 peratus iaitu sebanyak 1 juta pengguna di Malaysia. Jumlah peratusan pengguna media sosial di Malaysia adalah $81 \%$ berbanding jumlah populasi rakyat Malaysia dengan pengguna aktif sebanyak 26 juta pengguna. Pengguna dengan lingkungan umur 25-34 tahun adalah paling aktif di Facebook, Instagram dan FB Messenger di mana peratusan pengguna lelaki lebih 5.4 peratus dari pengguna wanita iaitu $20.9 \%$. 
DOI: https://doi.org/10.47405/mjssh.v6i4.745

Jadual 1: Penggunaan laman sosial tertinggi pada Januari 2020 berdasarkan lingkungan umur

\begin{tabular}{lc} 
Media sosial & $\begin{array}{c}\text { Peratusan berdasarkan lingkungan umur } \\
\text { 16-64 tahun }(\%)\end{array}$ \\
\hline Youtube & 93 \\
Whatsapp & 91 \\
Facebook & 89 \\
Instagram & 72 \\
Fb messenger & 63 \\
Twitter & 47 \\
\hline
\end{tabular}

Sumber: Simon (2020)

Berdasarkan jadual 1 Penggunaan laman sosial Facebook di Malaysia berada di peringkat ketiga dengan $55.3 \%$ pengguna lelaki dan $44.7 \%$ pengguna wanita dimana ada di kalangan mereka yang menggunakan internet untuk mengakses media sosial ini melalui pelbagai jenis telefon bimbit, komputer, komputer dan telefon bimbit mahupun telefon pintar. Di laman sosial seperti instagram dan twitter pula, ianya dimonopoli oleh kaum wanita dengan peratusan yang lebih tinggi berbanding lelaki. Di instagram pengguna wanita $53.0 \%$ dan lelaki $47.0 \%$. manakala, di twitter pengguna wanita sebanyak $67.2 \%$ berbanding lelaki iaitu $32.8 \%$ sahaja. Kebanyakan pengguna Malaysia di YouTube banyak membuat carian berkenaan dengan filem, drama, kartun, lagu dan juga video permainan yang dimuat naik oleh pemain (Simon, 2020).

\section{Pengguna Internet di Malaysia dari Aspek Jual-Beli Semasa Pandemik COVID-19}

Penggunaan e-dagang ketika pandemik COVID-19 ini mulai meningkat apabila kedai atau premis terpaksa ditutup. Oleh itu peniaga mula menguruskan perniagaan mereka dari rumah. Terdapat pelbagai platform pembelian atas talian yang mula mencanak naik seperti eBazar untuk membantu peniaga dalam menjalankan perniagaan mereka secara atas talian (Talha, 2020). Kajian yang dilakukan Rashid dan Hassan (2020) menunjukkan bahawa telah berlaku peningkatan dalam penggunaan aplikasi digital dalam perniagaan akibat daripada pandemik COVID-19 khususnya kepada peniaga kecil-kecilan. Ini bagi memastikan aktiviti perniagaan masih boleh diteruskan walaupun secara atas talian dan ada juga peniaga yang mendapatkan lebih banyak permintaan di luar jangkaan apabila mula berniaga secara atas talian.

Sebanyak $61 \%$ dari peratusan rakyat Malaysia yang berumur 16 hingga 64 tahun pada bulan Januari 2020 yang menggunakan aplikasi membeli-belah melalui telefon bimbit mereka untuk mencari barangan yang mereka ingin atau menjual barangan. 91\% pengguna dari kalangan umur 16 hingga 64 tahun yang membuat carian berkenaan produk dan juga perkhidmatan untuk dibeli dan digunakan. Manakala, 90\% dari lingkungan umur ini yang melawat beberapa laman sesawang pembelian secara atas talian dan $82 \%$ dari mereka yang membuat pembelian hasil daripada lawatan tersebut (Simon, 2020). Menurut Rafidah (2020) bermula Mac 2020 ketika pkp dikuatkuasakan di seluruh negeri dalam Malaysia, aktiviti jual beli dalam talian telah meningkat sebanyak 28.9 peratus pada bulan berikutnya. Namun beberapa industri francais telah mengalami kemerosotan dalam ekonomi mereka akibat daripada pendapatan yang kurang memberangsangkan terutama sekali dalam subsektor makanan dan minuman yang mencatatkan sebanyak 70\%. Oleh itu kerjasama antara persatuan francais Malaysia dan Shopee akan dilaksanakan bagi membantu dalam usaha menggalakkan perniagaan francais secara dalam talian.

Disebabkan COVID-19, banyak pengguna telah sedar akan penggunaan pembayaran secara atas talian. Oleh itu, setiap perkhidmatan atau barangan yang dijual atau dibeli akan memalui pembayaran secara atas talian yang memberikan impak kepada komunikasi tanpa perlu bersemuka. Seramai 39\% jumlah pengguna wanita yang berumur 15 tahun ke atas menggunakan perkhidmatan transaksi secara atas talian jika dibandingkan dengan lelaki 38\% sahaja. Selebihnya mereka akan pergi ke mesin juruwang automatik atau mana-mana kaunter perkhidmatan untuk membuat sebarang bayaran (Simon, 2020). Secara teknikalnya, penggunaan e-wallet juga merupakan antara kaedah yang digunakan untuk membuat transaksi sistem pembayaran. Dengan penggunaan ini ia dapat membantu kerajaan dalam 
mengurangkan penularan wabak ini (Hendy et al., 2020). Dalam tempoh pandemik di Malaysia ini juga, lebih banyak aplikasi yang melibatkan penggunaan $e$-wallet mula mendapat perhatian pengguna internet di Malaysia.

\section{Pengguna Internet di Malaysia dari Aspek Pekerja dan Pelajar Semasa Pandemik COVID- 19.}

Sesi pembelajaran dan pekerjaan dari rumah menyebabkan peningkatan dalam literasi penggunaan peranti elektronik seperti komputer dan juga telefon. Ini juga sekali gus meningkatkan kemahiran mengajar, belajar dan bekerja secara atas talian. Walau bagaimanapun penggunaan internet adalah terhad. Tidak semua rumah mempunyai rangkaian jalur lebar yang baik untuk membantu mereka mengakses internet. Tambahan pula, penggunaan internet di Malaysia semakin meningkat sepanjang tahun (Talha, 2020). Penggunaan aplikasi internet of things amat penting sepanjang tempoh pandemik ini untuk membantu hal-hal yang berkaitan dengan pekerjaan. Dalam aspek komunikasi seperti memberi arahan, perbincangan, dan sebagainya perlu dilakukan secara atas talian untuk meminimumkan pertemuan antara dua pihak secara bersemuka (Jamaluddin \& Mohammad, 2020). Pendekatan berasaskan teknologi ini memberikan cabaran dalam membiasakan diri dengan menggunakan alat teknologi dalam talian yang baru untuk, mengatasi kesulitan dalam mengakses internet, berlaku peningkatan beban kerja bagi memenuhi keperluan kerja dan hal-hal peribadi yang melibatkan psikologi,emosi atau sosial manusia itu sendiri (Azman et al., 2020).

Menurut Rafidah (2020) subsektor pendidikan mencatatkan penurunan ekonomi sebanyak $80 \%$ akibat daripada penutupan sekolah yang disebabkan oleh wabak COVID-19 ini. Aktiviti berkumpulan dalam pembelajaran juga akan dijalankan walaupun dengan jarak jauh yang melibatkan penggunaan aplikasi internet dan alat digital seperti Flipgrid, Zoom atau Webex. Pelajar juga akan dinilai melalui video pembentangan dan juga laporan yang telah dihantar secara atas talian (Azman et al., 2020). Walaupun pendidikan dijalankan secara atas talian namun ia juga mendatangkan kebimbangan tentang bagaimana menghasilkan pendidikan yang berkualiti (Burgess \& Sievertsen, 2020). Sebilangan pelajar yang menggemari pembelajaran secara atas talian melalui rakaman yang dibuat naik ke mana-mana pautan internet untuk memudahkan proses pembelajaran tanpa melibatkan gangguan internet apabila pembelajaran berlaku secara langsung (Ellen et al., 2020). Kerajaan, syarikat telekomunikasi dan universiti perlu membangunkan infrastruktur internet yang terbaik agar peningkatan dalam bidang pekerjaan dan pelajaran dapat disampaikan dengan lebih berkesan.

\section{Metod Kajian}

Kajian ini merupakan satu kajian deskriptif dimana kajian ini menggunakan reka bentuk kajian kuantitatif dan borang soal selidik sebagai instrumen. Sasaran responden bagi kajian ini adalah pengguna internet di seluruh Malaysia. Maklumat yang diperoleh tersebut dianalisis untuk menjawab persoalan kajian ini. Kaedah yang digunakan untuk mendapatkan maklumat mengenai persepsi pengguna internet semasa pandemik COVID-19 di Malaysia. Borang soal selidik ini diberikan kepada beberapa responden yang sudi memberikan kerjasama. Soalan telah diedarkan dalam bentuk Google Form. Responden diberikan masa beberapa hari untuk menjawab soalan yang dikemukakan di dalam borang soal selidik tersebut. Jumlah responden yang diperoleh adalah sebanyak 103 orang. Borang soal selidik ini terdiri daripada 2 bahagian iaitu bahagian A maklumat responden dan Bahagian B ialah persepsi pengguna internet di Malaysia semasa pandemik Covid19. Borang soal selidik ini juga menggunakan skor skala Likert dari 1 hingga 5, iaitu 1 (sangat tidak setuju), 2 (tidak setuju), 3 (kurang setuju), 4 (setuju) dan 5 (sangat setuju). Data yang telah diperoleh dianalisis menggunakan peratus, kekerapan dan min.

\section{Analisis Kajian}

\section{Analisis Demografi kajian}


DOI: https://doi.org/10.47405/mjssh.v6i4.745

Maklumat responden penting dalam kajian kerana maklumat tersebut menceritakan maklumat dan latar belakang responden untuk kajian. Latar belakang responden berbeza dapat memberi pandangan yang unik terhadap isu perbincangan tersebut. Antara maklumat responden yang dikajikan dalam kajian ini adalah jantina dan negeri asal responden.

Carta 1: Jantina

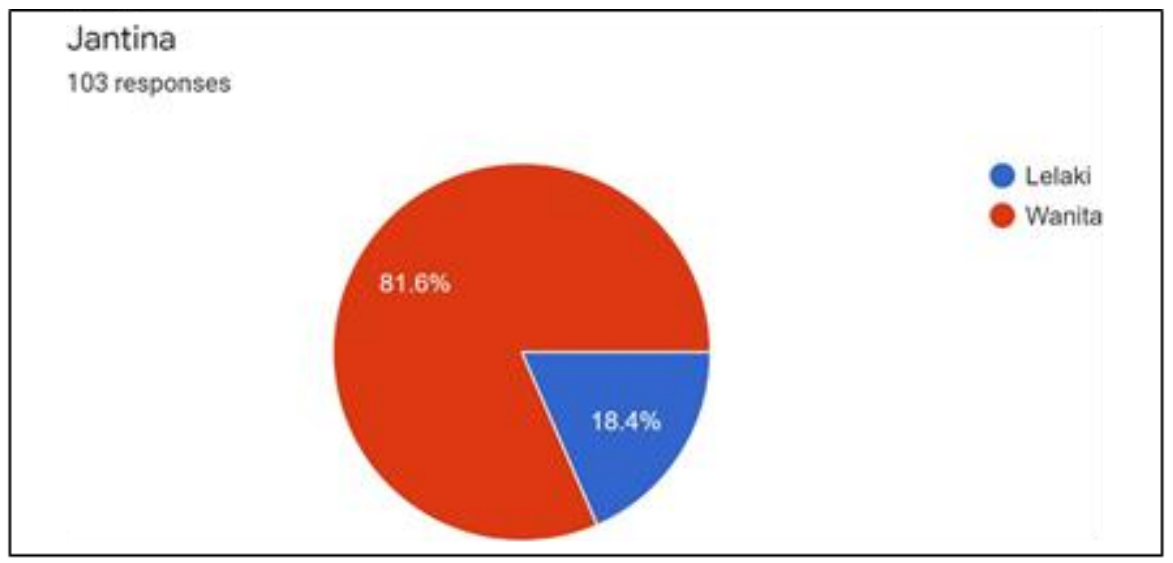

Carta 1 menunjukkan jumlah peratusan jantina responden dalam soal selidik kajian ini. Responden dalam kajian ini terdiri daripada 84 orang wanita dan 19 orang lelaki. Jumlah semua responden adalah seramai 103 orang dari semenanjung Malaysia. Seramai 82 peratus responden adalah merupakan responden wanita, manakala 18 peratus yang lain adalah merupakan responden lelaki. Carta ini menunjukkan terdapat peratusan responden wanita yang lebih banyak daripada responden lelaki dalam kajian yang dijalankan.

Carta 2: Tempat Asal

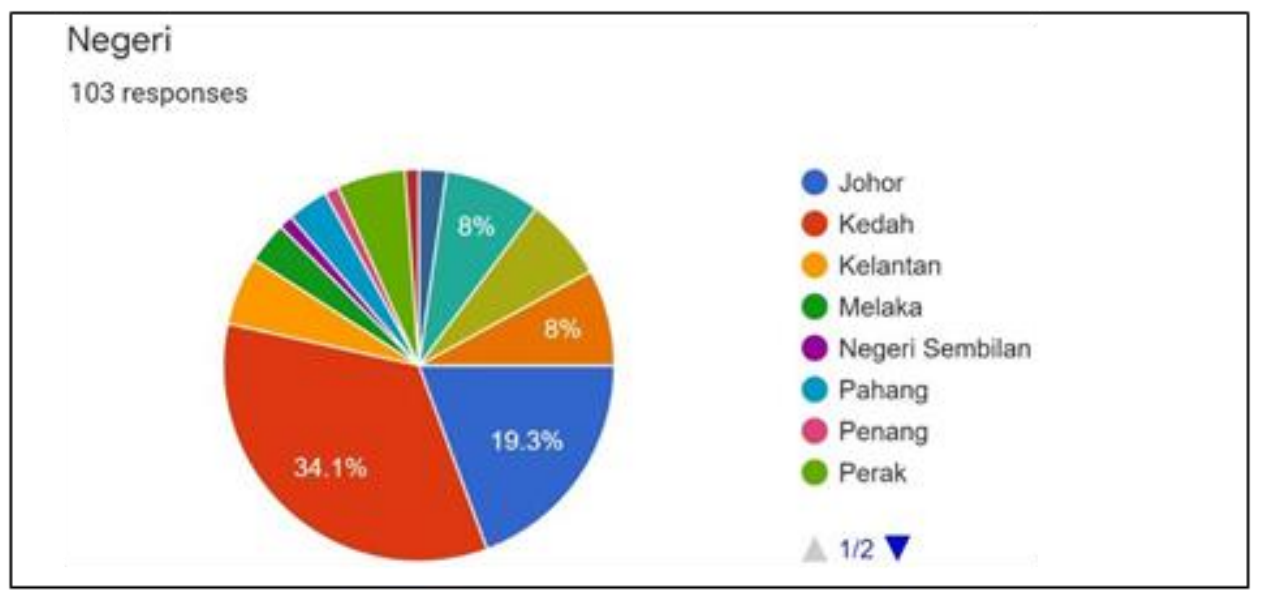

Maklumat negeri asal responden dikumpulkan untuk mendapatkan pendapat dan kedudukan responden dari negeri yang berbeza-beza di Malaysia. Maklumat negeri asal responden di seluruh Malaysia adalah dari negeri Johor, Kedah, Kelantan, Melaka, Negeri Sembilan, Pahang, Penang, Perak, Perlis, Sabah, Sarawak, Selangor, Terengganu, Kuala Lumpur, Wilayah Persekutuan Putrajaya dan Wilayah Persekutuan Labuan. Carta 2 menunjukkan jumlah peratusan negeri asal responden. Peratus paling tinggi dari negeri Kedah iaitu 34 peratus bersamaan 35 orang. Di ikuti responden dari negeri Johor seramai 20 peratus yang bersamaan 20 orang. Kemudian dari Putrajaya dan Selangor seramai 8 peratus yang bersamaan 8 orang. Seterusnya, Terengganu 7 peratus bersamaan dengan 7 orang. Responden dari negeri Kelantan dan Perak 6 peratus iaitu bersamaan dengan 6 orang, Melaka dan Pahang 4 peratus bersamaan dengan 4 orang serta dari Sabah 2 peratus yang bersamaan dengan 2 orang. Manakala satu peratus dari negeri Penang, Negeri Sembilan dan Perlis. Tiada responden dari negeri Sarawak dan Wilayah Persekutuan Labuan. Hal ini menunjuk jumlah responden dari Kedah melebihi 
DOI: https://doi.org/10.47405/mjssh.v6i4.745

responden dari negeri yang lain. Jumlah responden yang diperoleh adalah seramai 103 responden dari seluruh Malaysia.

\section{Analisa Maklum Balas Persepsi Pengguna Internet di Malaysia Semasa Pandemik COVID-19}

Bagi mengkaji persepsi pengguna internet di Malaysia semasa pandemik COVID-19, 10 item soalan telah dibina secara dalam talian. Jadual 2 menunjukkan peratusan dapatan kajian bagi setiap item untuk mengkaji persepsi pengguna internet di Malaysia semasa pandemik COVID-19.

Jadual 2: Persepsi pengguna internet di Malaysia semasa pandemik COVID-19

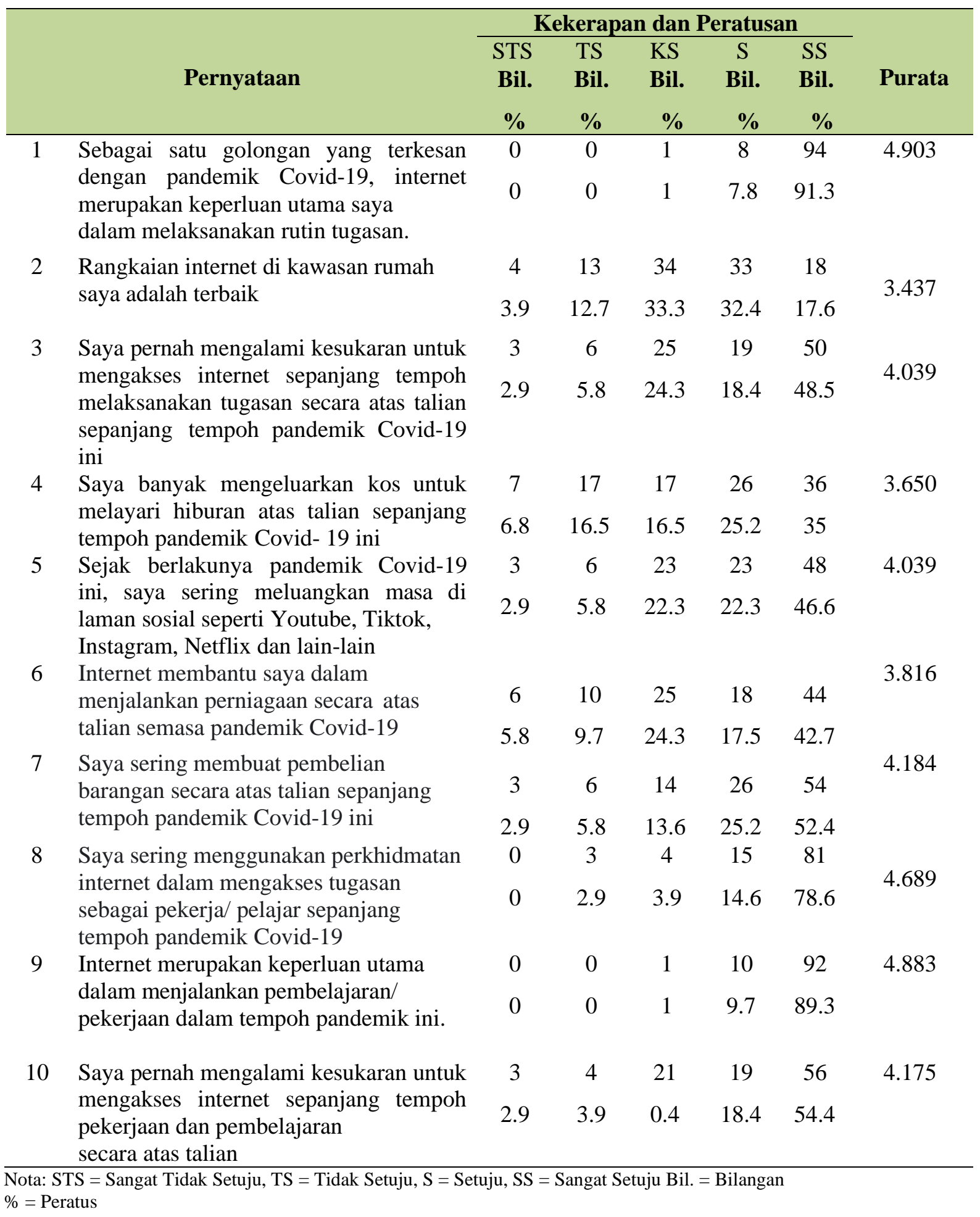


Jadual 2 di atas menyatakan kekerapan, peratus dan purata bagi 10 item soalan yang telah dibina untuk mengenal pasti persepsi pengguna internet di Malaysia semasa pandemik COVID-19. Melihat pada item dua menunjukkan peratusan setuju tertinggi iaitu 32.4\%. Manakala merujuk kepada item empat menunjukkan peratusan tidak setuju tertinggi iaitu 16.5\%. Bagi keseluruhan item persepsi pengguna internet di Malaysia semasa pandemik COVID-19 menunjukkan item satu mempunyai peratusan sangat setuju tertinggi iaitu 91.3\%. Ini menunjukkan bahawa terdapat responden yang bersetuju bahawa mereka terkesan dengan pandemik COVID-19, dimana internet merupakan keperluan utama dalam melaksanakan rutin tugasan harian. Malahan terdapat juga sangat tidak setuju yang tertinggi iaitu 6.8\% pada item keempat dimana responden beranggapan bahawa mereka tidak banyak mengeluarkan kos untuk melayari hiburan atas talian sepanjang tempoh pandemik Covid-19. Dari aspek purata, item soalan satu mempunyai jumlah purata yang tertinggi iaitu 4.903. Ini bermaksud ramai responden adalah sangat bersetuju atau bersetuju dengan soalan satu iaitu mereka terkesan dengan pandemik Covid-19, dimana internet merupakan keperluan utama dalam melaksanakan rutin tugasan harian. Manakala purata paling rendah terletak pada item soalan dua iaitu dengan pernyataan bahawa rangkaian internet di kawasan rumah mereka adalah terbaik yang hanya merekodkan 3.437.

\section{Perbincangan}

Perbincangan dapatan kajian ini adalah selaras dengan kajian yang dijalankan iaitu mengenai persepsi pengguna internet di Malaysia semasa pandemik COVID-19. Objektif utama kajian ini adalah untuk mengkaji persepsi pengguna internet di Malaysia semasa pandemik COVID-19. Bagi menjalankan kajian ini, 10 item soalan telah disediakan dan telah diedarkan secara atas talian melalui Whatsapp dan Facebook. Daripada edaran tersebut, ianya telah berjaya mendapat 103 responden seluruh Malaysia. Daripada itu, kajian ini telah mengumpulkan maklumat mengenai persepsi pengguna internet di Malaysia semasa pandemik COVID-19. Terdapat beberapa item yang disoal di dalam kajian ini iaitu, item yang pertama adalah mengenai demografi pengguna dan item kedua adalah mengenai persepsi pengguna di Malaysia berkenaan dengan internet.

Dapatan soal selidik analisis keperluan yang dijalankan ke atas 103 responden yang telah melibatkan pengguna internet di Malaysia menunjukkan bahawa internet merupakan satu keperluan utama dalam menjalankan tugas harian. Berdasarkan soal selidik, 91.3\% responden yang menyatakan bahawa mereka sangat setuju bahawa internat merupakan keperluan utama. Ianya tidak dapat dinafikan lagi kerana internet merupakan keutamaan dalam dunia yang kian moden ini. Walau bagaimanapun, terdapat cabaran yang perlu dihadapi oleh pengguna internet di Malaysia bagi menempuh alam pekerjaan dan pembelajaran semasa pandemik ini. Antaranya adalah kebolehcapaian internet dimana ianya merupakan salah satu aspek penting dalam mengendalikan pekerjaan atau pembelajaran secara atas talian. Cabaran yang kedua adalah pengurusan emosi dimana kerana pada awal perlaksanaan Perintah kawalan Pergerakan (PKP), pengguna akan mula bosan kerana terpaksa berkurung di rumah. Emosi pengguna akan terganggu kerana tidak dapat menjalankan aktiviti harian seperti biasa. Dalam hal ini, pengguna haruslah bijak dalam menangani kestabilan emosi masing-masing agar tidak berlaku masalah yang dapat memudaratkan diri masing-masing kelak.

\section{Kesimpulan dan Cadangan}

Penggunaan internet di Malaysia menunjukkan perubahan dan peningkatan dalam penggunaan internet yang dihadapi oleh rakyat Malaysia ketika pandemik COVID-19 ini. Dalam perubahan ini, pelbagai masalah, isu dan kesan akan timbul dalam kalangan individual atau masyarakat di negara ini. Kesukaran dalam mendapatkan talian internet merupakan salah satu isu tersebut. Pekerjaan merupakan sumber pendapatan untuk sebuah keluarga maka Walaupun pekerja tidak turun padang untuk meneruskan pekerjaan mereka sebaliknya bekerja dari rumah, mereka masih lagi perlu bekerja secara atas talian dengan menggunakan internet untuk berhubung seperti menghantar laporan dan lain-lain lagi. Kajian ini adalah untuk mengetahui tahap penggunaan internet di Malaysia semasa pandemik COVID-19 dari aspek hiburan, jual-beli serta pekerja dan pelajar. Dalam kajian ini mendapati penggunaan internet di Malaysia meningkat berbanding penggunaan sebelum pandemik COVID-19 
ini. Namun, sebahagian pengguna internet di Malaysia masih lagi mengalami gangguan untuk mendapatkan talian internet yang baik. Dapatan kajian ini sama seperti hasil literasi yang telah dikaji. Penggunaan Internet memang dapat membina suasana atau keadaan yang baru kepada pelbagai generasi terutama dalam situasi pandemik ini. Pelbagai perkara yang cuba diterokai oleh pengguna internet untuk menyesuaikan diri dengan keadaan dimana kebanyakan pekerjaan perlu dikerjakan secara atas talian. Daripada pandangan majoriti pengguna internet di Malaysia, mereka sedang bersedia untuk menyesuaikan diri dalam suasana yang mencabar dalam era ini. Akhir sekali, pengguna internet seharusnya memainkan peranan yang penting dalam menangani isu penggunaan internet dengan lebih mengambil tahu tentang perkara yang berkaitan dengan internet dan perlu aktif dalam menyesuaikan diri dalam situasi semasa yang berubah secara pantas.

\section{Rujukan}

Azlinda Azman, Paramjit Singh Jamir Singh, Jonathan Parker \& Sara Ashencaen Crabtree (2020) Addressing competency requirements of social work students during the COVID-19 pandemic in Malaysia. Social Work Education, 39(8), 1058-1065, DOI:10.1080/02615479.2020.1815692

BERNAMA. (2020, April 9). PKP punca aliran trafik internet tinggi?. Sinar Harian: https://www.sinarharian.com.my/article/78087/BERITA/Nasional/PKP-punca-aliran- trafikinternet-tinggi

Chung, E., Subramaniam, G., Dass, L. C. (2020). Online Learning Readiness among University Students in Malaysia amidst COVID-19. Asian Journal of University Education, 16(2), 46-58. https://eric.ed.gov/?id=EJ1267359

FMT Reporters. (2020, April 10). Free Malaysia Today. Laman web Free Malaysia Today: https://www.freemalaysiatoday.com/category/nation/2020/04/10/90-internet- access-in-malaysia/

Hanafiah, K. M., \& Wan, C. D. (2020). Public knowledge, perception and communication behavior surrounding COVID-19 in Malaysia. Preprint, Apr.

Hendy Mustiko Aji, Izra Berakon \& Maizaitulaidawati Md Husin (2020). COVID-19 and e-wallet usage intention: A multigroup analysis between Indonesia and Malaysia. Cogent Business \& Management, 7, 1, DOI:10.1080/23311975.2020.1804181

Jamaluddin, N. Mohamad, N. (2020). Pandemik Covid-19: Norma baharu dalam industri pembinaan di Malaysia.https://news.uthm.edu.my/ms/2020/05/pandemik-covid-19-norma-baharu-dalamindustri-pembinaan-di-malaysia/

Rafidah Mat Ruzki. (2020, June 19). Jualan dalam talian meningkat 28.9 peratus pada April. Berita Harian: $\quad$ https://www.bharian.com.my/berita/nasional/2020/06/701902/jualan-dalam-talianmeningkat-289-peratus-pada-april

Rashid, S. M. R. A., \& Hassan, F. (2020). Amalan dan penglibatan peniaga kecil melalui perniagaan digital semasa Pandemik COVID-19 di Malaysia. GEOGRAFI, 8(2), 1-20

Simon (2020, February 2018). Data Reportal - Global Digital Insights: https://datareportal.com/reports/digital-2020-malaysia

Simon Burgess, Hans Henrik Sievertsen (2020). The impact of COVID-19 on education | VOX, CEPR Policy Portal., Voxeu.org: https://voxeu.org/article/impact-covid-19-education

Speedtest Global Index - Monthly comparisons of internet speeds from around the world (2020). Speedtest Global Index: https://www.speedtest.net/global-index

Talha,R. (2020). Kajian kes impak perintah kawalan pergerakan kepada penduduk malaysia. Department of Statistics Malaysia Official Portal: https://www.dosm.gov.my/v1/uploads/files /6_Newsletter/Newsletter\%202020/DOS M_BPPD_1-2020_Siri-17.pdf 